\title{
Bogumita Mika*
}

University of Silesia, Katowice, Poland

Department of Fine Art and Music

Institute of Music

\section{'BENEATH THE SHADOW OF POLITICS'. RECEPTION OF THE MUSIC OF EDISON DENISOV IN POLAND}

\begin{abstract}
The music of Russian composer Edison Denisov was frequently presented in the Warsaw Autumn festival. Between 1964 and 2005, Polish audiences heard his pieces 21 times, including three world premieres. This music was widely received, especially in the 1960s and the 1970s, when Polish culture was strongly influenced by politics. The following decades brought changes in the context of politics and style in the arts, but Denisov's compositions continued to be performed in Warsaw. The aim of this paper is to present the opinions formulated by Polish music critics as evidence about the reception of Denisov's music.

Key words: Edison Denisov, reception, the Warsaw Autumn festival, critics, avant-garde, Russian music.
\end{abstract}

* Author contact information: mikabogumila@gmail.com 


\section{The political context in post-war Poland}

After the Second World War, all culture in Poland, including musical culture, was rigorously controlled by politics. The communist authorities imposed their doctrine of art, so-called 'socialist realism'. The infamous conference in Łagów Lubuski in Western Poland in 1949 officially condemned 'musical formalism' and proclaimed that only socialist realistic music could be written.

Political pressure prohibited artistic contacts with the West, including cooperation with foreign artists. Polish culture gradually became isolated from Western culture and art. Avant-garde music, comprising experiments with sound, was not welcome and was often banned.

The situation with art and culture changed to some extent after 1953, with the process of the political thaw that followed Stalin's death. As a result, the 'Warsaw Autumn' was established - the International Festival of Contemporary Music. It became a venue where both Eastern and Western composers met, a place where the most advanced avant-garde pieces were performed, an environment in which a free exchange of experience and views was possible.

Of course, although the political thaw had started in 1953, politics often still penetrated the areas of culture and music, especially during the 1960s and 1970s, influencing the repertoire of the Warsaw Autumn festival. It is against this background that frequent presentations at the Warsaw Autumn festival of the music of Russian composers such as Edison Denisov (1929-1996), Alfred Schnittke (1934-1998) and Sophia Gubaidulina (b. 1931) took place. As David Wright put it, these three "formed a trio of Soviet composers of the generation after Shostakovich, whose music has attracted serious attention in the West". What attracted Western attention was their modernistic music and progressive, highly individualistic sound language.

From the very beginning, the Polish press generously covered the Warsaw Autumn festival - daily newspapers as well as journals and magazines dedicated to music, musicology and culture, generally. The most important Polish musical publication was - and still is - the music journal Ruch Muzyczny, published twice a month, beginning in 1945, in Warsaw. I shall describe the Polish reception of Edison Denisov's music based on the reviews and relations published in Ruch Muzyczny and deepened with reference to information from the musicological journal Res Facta.

1 David Wright, "Peinture: Some Thoughts on Denisov", The Musical Times, 1991, 132242. 
Mika, B.: 'Beneath the shadow of politics'. Reception of the music of Edison Denisov...

\section{Denisov's music in Poland}

Denisov's music was frequently heard in the Warsaw Autumn festival concerts. The Polish audience heard his pieces 21 times (two pieces in 1986), including three world premieres. ${ }^{2}$ The first composition was performed in 1964, the last in 2005. Even during the worst defamation campaign against him and the years when he was excluded from the circle of composers welcome to perform in the Eastern Bloc countries - 1972 - one of his works was presented under the name of his wife, Gala Warwarin.

It is worth mentioning here that a detailed analysis of the reviews published on the pages of Ruch Muzyczny show that as many as seven presentations of Denisov's music received no comment at all. They were compositions performed in 1968, 1969, 1970, 1985, 1989, 1994, 1997, as follows:

- in 1968 - Crescendo e diminuendo (1965), ${ }^{3}$

- in $1969-D-S$ - $C$ - $H(1969)$ for clarinet, trombone, cello and piano, ${ }^{4}$

- in 1970 - Three pieces [3 p'yesi] (1967) for cello and piano, ${ }^{5}$

- in 1985 - Trio for oboe, cello and piano (1981), ${ }^{6}$

- in 1989 - Clarinet Quintet (1987), ${ }^{7}$

- in 1994 - In memoriam Witold Lutosławski, ${ }^{8}$

- in 1997 - Chamber Symphony No. 2 (1994). ${ }^{9}$

Nevertheless, during the period described in this paper, three interviews with Denisov were published in Ruch Muzyczny: in 1969, 1976 and 1989. In each, the composer commented on his musical output and on the general situation that prevailed in Soviet music.

Exactly how was Denisov's music received in Poland? What can we learn from the reviews published in Ruch Muzyczny during this period? Let us start a detailed analysis.

\footnotetext{
2 World premieres were: $D-S-C-H$ in 1969, Pain and silence in 1979 and In memoriam Witold Lutostawski in 1994.

3 Performed by Sofia Chamber Orchestra under Vassil Kazandijev.

4 Played by 'Warsztat Muzyczny' - Polish group performing avant-garde music.

5 Played by Palm and Aloys Kontarsky.

6 Performed by 'Trio Aulos': Burkhard Gleetzner - oboe, Wolfgang Weber - cello, Gerard Erber - piano.

7 Played by Eduard Brunner and The Wilanów Quartet.

8 Played by Sinfonietta Cracovia under Wojciech Michniewski.

9 Played by Moscow Conteporary Music Ensemble under Alexei Vinogradov.
} 


\section{Reviews ...}

The Concerto for flute, oboe, piano and percussion $(1963)^{10}$ was the first composition by Denisov to be performed at the Warsaw Autumn, in 1964. The reviewer of Ruch Muzyczny praised it in these words:

The following movements of this piece seemingly prove the stylistic evolution of the composer's technique. After the neo-classical (recapitulation), although atonal, first movement, the second follows as a cycle of four solo cadenzas, between which the flute cadenza is the most distinctive innovation. The piece closes with a short third movement, in which the composer uses punctualism subtly predicted in the first part. The concerto is not characterized by stylistic homogeneity, but is composed in good taste and makes pleasant hearing. ${ }^{11}$

The reviewer also emphasized that the music made a very good impression on the listeners. ${ }^{12}$

In 1966, another reviewer, Bohdan Pilarski, commented on Denisov's The Sun of the Incas (1964), ${ }^{13}$ for soprano and 11 instruments. He cited it as an example of music that heralded changes in the style of Soviet composers, a style hitherto hermetic and almost inaccessible to outside influences.

The year 1972 saw strongly political entries both in the repertoire of the Warsaw Autumn festival and on the pages of Ruch Muzyczny. In that year, an intense renewal of cooperation was initiated between Poland and the USSR. An influential delegation from the Soviet Composers' Union came to the Warsaw Autumn, and many important meetings (summit talks) between political and cultural leaders of both countries (Poland and the USSR) took place. The Soviet delegation was led by the leader of the Soviet Composers' Union, Tikhon Khrennikov, ${ }^{14}$ and among the group's members were the famous Soviet composers Aram Khachaturian ${ }^{15}$ and Riodon Shchedrin. ${ }^{16}$

10 Played by: Petr Kotik - flute, David Lang - oboe, David Wilde - piano, Ivo Kieslich percussion.

11 [kb], "Czwartkowy koncert kameralny" [Chamber concert on Thursday], Ruch Muzyczny, $1964,22,11$.

12 Ibid., 11.

13 With Berthe Kal - French soprano.

14 Khrennikov was a composer and a pianist but his bad reputation was connected with its role as General Secretary of the Soviet Composers's Union.

15 Who, for 25 years, has been already the professor of composition at the Moscow Conservatory.

16 The Soviet delegation was formed by: Tikhon Khrennikov, Riodon Shchedrin, Peter Savincev, Eduard Mirsojan, Myroslav Skoryk, Grigori Shirma, Boris Körver, Andrei Bałanchivadze, Andrey Pietrov, Serafin Tuchkov, Jurij Korev, Albert Leman, Gedert Raman, Yury Keldish and Gara Garayev. 
Mika, B.: 'Beneath the shadow of politics'. Reception of the music of Edison Denisov...

In that year, Denisov's music was banned and his name excluded from the official list of Soviet composers, making it impossible to perform his music openly in Poland. But Denisov was included in the musical project called $E N$ $K Y K L O P A I D E I A$, and his music was heard under his wife's name, Gala Warwarin. ENKYKLOPAIDEIA was a collection of 15 pieces by 15 foreign composers, ${ }^{17}$ compiled at the request of the Polish composer Zygmunt Krauze, the leader of the 'Warsztat Muzyczny' group.

Mirosław Kondracki, the reviewer for Ruch Muzyczny, focused on the idea of the project rather than on the music itself. He wrote that ENKYKLOPAIDEIA had been planned as a "very interesting quodlibet", 18 but that it discouraged its audience. The 15 pieces of music were performed anonymously, separated by pauses of silence. It confused listeners not to know which piece had been written by which composer, and consequently, this made it impossible for them to properly welcome the "big names".

Even in 1973, Ruch Muzyczny dedicated much of its attention to Soviet music. On the occasion of the Warsaw Autumn, Polish composer Witold Rudziński (1913-2004) published an entire article entitled "Music of Our Neighbours". In this article, Rudziński particularly praised Romantic Music (1968) by Denisov (for oboe, viola, cello and harp). ${ }^{19}$ Rudziński described the piece as "strikingly inventive; of mature content, form and means; strongly emotional; brightly coloristic". ${ }^{20 .}$

The review published in 1976, also emphasized the value of Denisov's music. Its author [jk - Józef Kański] considered Denisov the outstanding representative of new Soviet music, ${ }^{21}$ and described the composition Peinture ${ }^{22}$ (1970) for orchestra, inspired by a painting by Boris Bürger as an "excellent work, engaging both for its originality and its simplicity, its internal cohesion and logic". ${ }^{23}$

17 Members of the ENKYKLOPAIDEIA project were composers: Louis Andriessen, Giuseppe Chiari, Mormon Feldman, Luc Ferrari, Vinko Globokar, Mauricio Kagel, Arne Nordheim, Per Norgaard, Luis de Pablo, Carlos Roque Alsina, Frederic Rżewski, Dieter Schönbach, Aurel Stroe, Gala Warwarin, Karl Erik Welin.

18 Mirosław Kondracki, “A na 'Jesieni' wiosennie (II)" [There is 'Spring' in an Autumn], Ruch Muzyczny, 1972, 24, 7-8.

19 Performed by Gruppe Neue Musik Hanns Eisler under Max Pommer.

20 Witold Rudziński, "Muzyka naszych sąsiadów" [Music of our Neighbours], Ruch $\mathrm{Mu}$ zyczny, 1973, 22, 7.

21 [jk], "Michniewski i Filharmonia Słoweńska" [Michniewski and The Slovak Philharmonic], Ruch Muzyczny, 1976, 22, 12.

22 Played by Slovak Philharmonic under Wojciech Michniewski.

23 [jk], op. cit., 12. 
The next commentary on the music of Denisov was published in Ruch Muzyczny two years later, in 1978, when the author [mg - Małgorzata Gąsiorowska] discussed both the good and bad points of his Sonata for solo clarinet ${ }^{4}$ (1972). The reviewer wrote: “The work by Denisov is not, by any means, a masterpiece. It could satisfy listeners only with the nobility of the composer's intention, the internal discipline, formal order and the consequence of its ideas". ${ }^{25}$

The cycle of songs Pain and Silence (1979) after Osip Mandelstam, for mezzo-soprano, clarinet, viola and piano, which premiered in Warsaw in 1979, was condemned by Ruch Muzyczny reviewer Olgierd Pisarenko as music that evoked no vivid emotions. ${ }^{26}$ Pisarenko, however, pointed out the subtle and deep lyricism and the economical technique of Denisov's composition, placing responsibility for the collection's unsuccessful performance on the performers ("Ars cameralis" and Zuzana Matouškova from Prague).

In 1981 again, Olgierd Pisarenko reviewed Denisov's music at the Warsaw Autumn, which had programmed his Concerto for flute, oboe and orchestra (1978). ${ }^{27}$ Pisarenko heard "dense, colourful, simply glimmering music, with complicated dramatic action, slightly similar to Ligeti, but not especially spontaneous". ${ }^{28}$

The presentation of his Requiem (1980) ${ }^{29}$ during the opening ceremony of the Warsaw Autumn festival in 1983 is considered to be the most important concert of Denisov's music. Elżbieta Szczepańska-Malinowska roundly praised the event, designating Denisov's works "impatiently awaited and remembered for a long time" 30 marked by "extraordinary compactness of development". ${ }^{31} \mathrm{Her}$ opinion of the Requiem as a composition, however, was not enthusiastic. Szczepańska-Malinowska emphasized that Denisov, in Requiem, is "still recogniz-

24 Played by Andrzej Godek - clarinet.

25 [mg], "Warszawska Jesień 78: Kanadyjczycy" [Warsaw Autumn 78: Canadians], Ruch Muzyczny, 1978, 22, 12.

26 [op], "Latwe zwycięstwo szkoły polskiej" [Easy victory of the Polish School], Ruch Muzyczny, 1979, 22, 8.

27 Performed by Aurèle Nicolet, Heinz Holliger, Philharmonic Orchestra of Lodz under Andrzej Markowski.

28 Olgierd Pisarenko, "Festiwalowy brulion; XXV Międzynarodowy Festiwal Muzyki Wspólczesnej Warszawa 18-27 września 1981" [Festival's booklet: 25th International Festival of Contemporary Music. Warsaw 18-27 September 1981], Ruch Muzyczny, 1981, 23, 8.

29 Requiem was performed by: Elżbieta Towarnicka - soprano, Piotr Kusiewicz - tenor, National Philharmonic Symphony Orchestra and Choir under Kazimierz Kord.

30 Elżbieta Szczepańska-Malinowska, "Powrót 'Warszawskiej Jesieni', powrót do obowiązku" [The comeback of 'Warsaw Autumn', comeback to duty.], Ruch Muzyczny, 1983, 22, 4.

31 Ibid., 4. 
Mika, B.: 'Beneath the shadow of politics'. Reception of the music of Edison Denisov...

able", 32 but also noted that "he became a different musical personality. He tried to 'Byron-ise', to play poetic moments in a romantic way. He supported these efforts with elements of traditional form and tonal harmony". ${ }^{33}$ The last, however, did not, in her opinion, fit his compositional style, and resulted in a work that had lost much of its value. Finally, Szczepanska-Malinowska admitted that it was difficult for her to evaluate Requiem after a single hearing, but that, personally, she preferred the 'former Denisov'. ${ }^{34}$

The Warsaw Autumn festival in 1986 presented two pieces by Denisov, but they were only briefly and negatively reviewed by Dorota Szwarcman. She described Three pictures after Paul Klee $e^{35}$ (1985) as sad pieces that "had little in common with the paintings of Paul Klee", ${ }^{36}$ although claiming them as inspiration. Szwarcman also accused Variations on Haydn's Canon 'Tot ist ein langer Schlaf' for cello and orchestra (1982) by Denisov ${ }^{37}$ of sadness, boredom and even aimlessness. The reviewer ironically concluded that after hearing these Variations one might have suggested that it is music that 'ist ein langer Schlaf' (that 'is a long sleep'). ${ }^{38}$ Stefan Kisielewski, the most influential Polish music critic, did not write a word about Denisov's music, although he commented - in the light of politics - on the pieces of the other Soviet composers, such as Galina Ustwolskaya and Giya Kancheli.

The Warsaw Autumn festival of 1988 was reviewed, among others, by Polish composer Edward Sielicki, who also criticized Denisov's music. Sielicki wrote about Nuages noires [Black Clouds] (1984) for solo vibraphone: "I irresistibly associated the aesthetics of this piece with film music. The work was too languid, made incongruous by the too-frequent use of maximum vibrato" ${ }^{39}$

The Warsaw Autumn festival in 1990 was marked by events that were important for the Polish audience, including the visit by emigrant composer Andrzej Panufnik and the presentation of music by George Crumb. Nevertheless,

\footnotetext{
32 Ibid.

33 Ibid.

34 Ibid.

35 Three pictures after Paul Klee for viola, oboe, vibraphone, piano and contrabass was played by Matthias Buchholz - viola and Ensemble Modern under Heinz Holliger.

36 Dorota Szwarcman, "Z dziennika wytrwałej shuchaczki” [From the diary of tenacious listener], Ruch Muzyczny, 1986, $23,7$.

37 Played by Ivan Monighetti and Orchestra of Symphony of Georgia SRR under Jansug Kakhidze.

38 Dorota Szwarcman, op. cit., 7.

39 Edward Sielicki, "Warszawska Jesień '88" [Warsaw Autumn'88], Ruch Muzyczny, 1988, 23,12 .
} 
musicologist Leszek Polony took note of Denisov's The Blue Book [Sinyaya kni$g a]$ (1984), ${ }^{40}$ written for narrator, soprano, violin, cello and two pianos, to texts by Russian poets and victims of Stalin's repression Alessandr Vedensky and Daniil Kharms. Polony included The Blue Book among his list of the important music written in the 1980s which would, he said, long remain in listeners' memories. He directed attention to the poetic dimension of the musical scenes which he called "alternately elegiac and irrationally - humoristic"41 - and to the beautiful, romantic song of the soprano as a finale. ${ }^{42}$

The Concerto for flute, vibraphone, harpsichord and string orchestra (1993) ${ }^{43}$ by Denisov, performed in 1996, received commentary in Ruch Muzyczny by Bolesław Blaszczyk. It is necessary to mention that this review of the music of Denisov served as a mere pretext for complimenting the young flute soloist Natalia Rochacka, at that time still a student at the Warsaw Music Academy. The review read, in part, "In Denisov's piece everything is a fragile ornament. The filigree-adept flutist, with her playing, created ornament upon ornament". ${ }^{44}$ Nothing more was written of Denisov's music except for the conclusion that "this otherwise beautiful whole was not sufficiently interesting". ${ }^{45}$

The last instance of the performance of music by Denisov during this period of the Warsaw Autumn festivals was in 2005, when Michal Mendyk, in an article entitled "Russian roulette," wrote with praise:

the strongest accent [of the concert] was undoubtedly the work of the icon of the Russian Avant-garde, Edison Denisov. In his The Woman and the Birds ${ }^{46}$ (1996), the progressive organization of material, rooted in dodecaphony, was united by such ideals of classical chamber style as: sublimation and diversity of a complex texture and a multileveled, though organically coherent, construction. We heard a masterpiece, which was impressive in the way a painting is and which was, at the same time, not devoid of dramatic skills. ${ }^{47}$

40 Performed by: Adam Ferency - narrator, Tatyana Poluektova - soprano, Ewa Marczyk - violin, Kazimierz Koślacz - cello, Szábolc Esztényi and Jerzy Witkowski - two pianos, Małgorzata Dziewulska - staging.

41 Leszek Polony, "Koniec nowego romantyzmu" [The end of New Romanticism], Ruch Muzyczny, 1990, 21, 4.

42 Ibid., 4.

43 Played by Natalia Rochacka, Piotr Maślanka, Dorota Frąckowiak-Kapała, Amadeus Chamber Orchestra of Polish Radio under Agnieszka Duczmal.

44 Bolesław Błaszczyk, "Z Poznania i ze Lwowa" [From Poznan and from Lviv], Ruch Muzyczny, 1996, 23, 15-16.

45 Ibid.

46 Played by Moscow Contemporary Music Ensemble under Alexey Vinogradov.

47 Michał Mendyk, "Rosyjska ruletka" [Russian roulette], Ruch Muzyczny, 2005, 22, 14. 
Mika, B.: 'Beneath the shadow of politics'. Reception of the music of Edison Denisov...

\section{....and interviews}

Ruch Muzyczny published three interviews with Edison Denisov between 1964 and 2005: in 1968, 1976 and 1989. In the first interview (1968), part of a series called "Festival conversations," Denisov talked about his composing plans, about the general situation of Soviet music of that time and about his relationship to Polish music. From the interview we learned that Denisov had attended the Warsaw Autumn many times and that his new piece $D-S-C-H$, performed in 1969 , was a success. Denisov characterized Soviet music as incessantly searching for new means of expression, ${ }^{48}$ and their representative composers as persons demonstrating great dedication to their work. ${ }^{49}$

The next interview (1976) ${ }^{50}$ dealt with a different topic. The composer evaluated the importance of festivals of contemporary music and admitted that he preferred his music to be on the programme at regular symphony concerts rather than in festival performances (only two of his pieces premiered at festivals: the Cello concerto and the Concerto for flute and orchestra). He also emphasized that he considered himself to be a Russian composer who did not need the 'Russian clothes' of the Russian folk quotation for his music (as Stravinsky did, for example, who composed music 'a la russe'. ${ }^{51}$ )

The third interview with Denisov was published in 1989,52 in the period after the political changes in the Eastern Bloc countries. Denisov offered his views about the important Soviet music composed in the 1920s and 1930s which, because of political reasons, had remained in the background of classical music to the present time. He compared this situation to the injustice his generation had suffered: he, himself, Alfred Schnittke and Sophia Gubaidulina. The relationship of the Soviet Composers' Union had for many years been ill-disposed toward them. His compositions: Peinture $(\dot{Z} y$ wopis' $=$ Painting) and the cantata The Sun of the Incas were barred from performance, not only in the USSR but also in Ljubljana (the former Yugoslavia), Sofia (Bulgaria) and East Berlin. ${ }^{53}$ Denisov's declaration points out that all the countries that were members of the Eastern

\footnotetext{
48 tg, "Festiwalowe rozmowy: Edison Denisow" [Festival conversations: Edison Denisov], Ruch Muzyczny, 1969, 23, 14.

49 Ibid., 14.

50 "Warszawska Jesień 1976, Edison Denisow, mówi radziecki kompozytor, autor utworu Peinture" [Warsaw Autumn 1976, Edison Denisov speaks, the Soviet composer, author of Peinture], Ruch Muzyczny, 1976, 24, 15.

51 Ibid, 15.

52 Olga Ilczenko, “AB OVO: nowe spojrzenie na muzykę radziecką" [AB OVO: New look at Soviet music], Ruch Muzyczny, 1989, 6, 17-18.

53 Ibid., 17.
} 
Bloc had to subordinate themselves to orders from the USSR (or, specifically in the domain of music, from the Soviet Composers' Union).

In addition to articles in Ruch Muzyczny, texts about Denisov were published in the Polish musicological journal 'Res Facta', which was very important to scholars but very exclusive in its target readership. ${ }^{54}$ It focused on contemporary music: the publication's subtitle reads: "Texts about contemporary music". In 1972, in its sixth volume, two lengthy essays dedicated to Denisov's music were published, written by musicologist Valentina N. Kholopova ("New compositions of E. Denisov, 1968-69") 55 and by composer Alfred Schnittke ("Edison Denisov"). ${ }^{56}$ This copious study of Denisov's creative personality probably resulted from the close friendship between the publication's editor-in-chief, Polish musicologist Michał Bristiger and Denisov.

Both authors - Kholopova and Schnittke - thoroughly analyzed selected pieces by Denisov, and Schnittke also emphasized that he considered Denisov's talent to be original, though it had 'fermented' for a long time..$^{57}$ In a postscript to his article, he admitted that he had altered his attitude to Denisov. Whereas formerly he had concentrated on Denisov's compositional technique, now - in 1969 - he recognized new characteristics. He expressed this new attitude in the following sentences:

The value of a composer does not lie in his subtle decisions on which technique to use but in the interior forces that inspire his musical output. And these forces - as do all forces, in order not to collapse - constantly need new impulses. ${ }^{58}$

\section{Conclusion}

What portrait of Denisov's music reception can we draw after reading this body of reviews, interviews and analyses?

We may note that Denisov's music, presented in Poland over a long period of time (1964-2005), resonated for more than 40 years with all the stylistic trends important to Polish music and its audiences. Denisov's compositions written in the 1960s and 1970s - giving proof of Soviet interest in the Avant-garde - were enthusiastically accepted by Polish critics and listeners, an enthusiasm

\footnotetext{
54 Published by Polish Music Edition since 1967.

55 Valentina Kholopova, "Nowe kompozycje E. Denisowa 1968-69" [New compositions of

E. Denisov, 1968-69], Res Facta, 1972, 6, 126-132.

56 Alfred Schnittke, "Edison Denisow", Res Facta, 1972, 6, 109-125.

57 Ibid., 109.

58 Ibid., 124.
} 
Mika, B.: 'Beneath the shadow of politics'. Reception of the music of Edison Denisov...

similar to the reception of all avant-garde and progressive musical trends heard in those decades in Poland.

If the music critics did not write about some performances of Denisov's music $(1968,1969,1970)$, we may place responsibility at the feet of the powerful political influence of the USSR, which at that time condemned the Avant-garde among young Soviet composers. Poland, as a part of the Eastern Bloc, was to some extent subordinate to the edicts of its Eastern Neighbour.

The year 1968, when political events had a strong impact on the repertoire of the Warsaw Autumn festival, seems to be especially meaningful in that context. In direct reaction to the Polish participation in the Warsaw Pact forces' attack on Czekoslovakia in March 1968, a group of performers from Western Europe refused to attend the 1968 Warsaw Autumn festival. Contrary to the desires of the organizers, the music of Soviet and Bulgarian composers dominated the repertoire of the festival that year. But contrary to the intention of the political powers, these presentations received no comment at all in the Polish musicological press, and the Warsaw Autumn itself was only briefly described in Ruch Muzyczny in two general articles. The most attention was paid to Polish music, which was judged to be more interesting to Polish readers.

A more critical opinion about Denisov's music, published in the Polish musical press in the 1980s and 1990s, or even the lack of any commentary in 1985 , $1989,1994,1997$, can be associated with the aesthetical changes that occurred in Polish music itself, with a distinct turn to postmodern values (especially New Romanticism). Against this background, the avant-garde compositions of Denisov, as well as avant-garde music generally, were no longer new, nor interesting, nor attractive.

Then, too, regaining real independence after 1989 made it possible for outstanding immigrant Polish composers to visit Poland, notably Andrzej Panufnik, and for ordinary listeners' attention to concentrate on music by native composers. Compositions by Soviet composers, even the best, receded from prominence into the background.

A positive review published in 2005 , the last in the period I have discussed here, can give evidence of the new state of consciousness of Polish listeners on the threshold of the $21^{\text {st }}$ century. For them Denisov's music is a good example of Soviet avant-garde experimentation. Unfortunately, it coincided with the unhappy period of political domination by the USSR over Poland. For this reason Denisov's musical output was, at the time, marginalized or even omitted, and is now forgotten. His music in Poland still awaits a new renaissance. 


\section{Appendix}

\section{Compositions by Denisov performed at Warsaw Autumn festival}

1964 - Concerto for flute, oboe, piano and percussion (1963)

1966 - Le soleil des Incas (Солнче инков - The Sun of Incas), (1964) text by Gabriela Mistral for soprano, flute, oboe, horn, trumpet, two pianos, percussion, violin and cello

1968 - Crescendo e diminuendo (1965)

$1969-D-S$ - $C-H$ (1969) for clarinet, trombone, cello and piano

1970 - Three pieces [3 p'yesï] (1967) for cello and piano

1973 - Musique Romantique (Романтическая музыка - Romantic Music) (1968) for oboe, harp and string trio

1976 - Peinture (Живопись - Painting) (1970) for orchestra

1978 - Sonata for clarinet solo (1972)

1979 - Pain and Silence (1979) after Osip Mandelstam for mezzo-soprano, clarinet, viola and piano

1981 - Concerto for flute, oboe and orchestra (1978)

1983 - Requiem (1980) after liturgical texts and poems by Francisco Tanzer for soprano, tenor, mixed chorus and orchestra

1985 - Trio for oboe, cello and piano (1981)

1986 - Three Pictures after Paul Klee (1985) for viola, oboe, horn, piano, vibraphone and double bass

1986 - Tod ist ein langer Schlaf (Смерть - это долгий сон - Death is a Long Sleep) (1982) Variations on Haydn's Canon for cello and orchestra

1988 - Nuages noires [Black Clouds] (1984) for vibraphone solo

1989 - Clarinet Quintet (1987)

1990 - The Blue Book [Sinyaya kniga] (1984) for narrator, soprano, violin, cello and two pianos to the texts by Alessandr Vedensky and Daniil Kharms

1994 - In memoriam Witold Lutostawski

1996 - Concerto for flute, vibraphone, harpsichord and string orchestra (1993)

1997 - Chamber Symphony No. 2 (1994).

2005 - Femme et oiseaux (The Woman and the Birds) (1996) homage to Joan Miro for piano, string quartet and woodwind quartet 
Mika, B.: 'Beneath the shadow of politics'. Reception of the music of Edison Denisov...

\section{References}

Błaszczyk, Bolesław: "Z Poznania i ze Lwowa" [From Poznan and from Lviv], Ruch Muzyc$z n y, 1996,23,15-16$.

Denisow, Edison: "Warszawska Jesień 1976, Edison Denisow, mówi radziecki kompozytor, autor utworu Peinture" [Warsaw Autumn 1976, Edison Denisov speaks, the Soviet composer, author of Peinture], Ruch Muzyczny, 1976, 24, 15.

Gąsiorowska, Małgorzata/[mg]: "Warszawska Jesień 78: Kanadyjczycy" [Warsaw Autumn 78: Canadians], Ruch Muzyczny, 1978, 22, 12.

Ilczenko, Olga: “AB OVO: nowe spojrzenie na muzykę radziecką" [AB OVO: New look at Soviet music], Ruch Muzyczny, 1989, 6, 17-18.

[jk], "Michniewski i Filharmonia Słoweńska" [Michniewski and The Slovak Philharmonic], Ruch Muzyczny, 1976, 22, 12.

Kholopova, Valentina, "Nowe kompozycje E. Denisowa 1968-69" [New compositions of E. Denisov, 1968-69], Res Facta, 1972, 6, 126-132.

Kondracki, Mirosła:, "A na 'Jesieni' wiosennie (II)" [There is 'Spring' in an Autumn], Ruch Muzyczny, 1972, 24, 7-8.

[kb]: "Czwartkowy koncert kameralny" [Chamber concert on Thursday], Ruch Muzyczny, 1964, 22, 11.

Mendyk, Michał: "Rosyjska ruletka" [Russian roulette], Ruch Muzyczny, 2005, 22, 14.

Pisarenko, Olgierd: "Latwe zwycięstwo szkoły polskiej" [Easy victory of the Polish School], Ruch Muzyczny, 1979, 22, 8.

---: "Festiwalowy brulion; XXV Międzynarodowy Festiwal Muzyki Współczesnej Warszawa 18-27 września 1981" [Festival's booklet: 25th International Festival of Contemporary Music. Warsaw 18-27 September 1981], Ruch Muzyczny, 1981, 23, 8.

Polony, Leszek: "Koniec nowego romantyzmu" [The end of New Romanticism], Ruch Muzyczny, 1990, 21, 4.

Rudziński, Witold: "Muzyka naszych sąsiadów" [Music of our Neighbours], Ruch Muzyczny,

$1973,22,7$.

Schnittke, Alfred: "Edison Denisow", Res Facta, 1972, 6, 109-125.

Sielicki, Edward: “Warszawska Jesień '88” [Warsaw Autumn'88], Ruch Muzyczny, 1988, 23, 12.

Szczepańska-Malinowska, Elżbieta: "Powrót 'Warszawskiej Jesieni', powrót do obowiązku"

[The comeback of 'Warsaw Autumn', comeback to duty.], Ruch Muzyczny, 1983, 22, 4.

Szwarcman, Dorota, "Z dziennika wytrwałej słuchaczki" [From the diary of tenacious listener], Ruch Muzyczny, 1986, 23, 7.

[tg], "Festiwalowe rozmowy: Edison Denisow" [Festival conversations: Edison Denisov], Ruch Muzyczny, 1969, 23, 14.

Wright, David: “Peinture: Some Thoughts on Denisov", in: The Musical Times. 1991, 132242. 